\title{
Growing the critical thinking of schoolchildren in Taiwan using the Analects of
}

\section{Confucius}

\begin{abstract}
According to research, the value of cultivating thinking in the context of dialogic teaching is an effective strategic approach to critical thinking. This study applied an extended comparative intervention to six classes of Taiwanese schoolchildren using two types of experimental groups. Two classes of each different age group were engaged in dialogic teaching over a 12-week period with the use of different materials, either the Analects of Confucius or moral dilemma stories. Three further classes served as control groups. The results of a detailed content analysis demonstrated that this dialogic intervention in the class type of the Analects contributed significant gains in the thinking of exploratory talk.
\end{abstract}

Keywords: critical thinking, dialogic teaching, content analysis, moral dilemmas, the Analects of Confucius 


\section{Introduction}

In early times, Confucian ethics were the main guiding principle in Taiwanese education. This theory arguably also provided a strong and culturally resonant context for stimulating thought about the nuances of moral issues. However, with changes in Taiwanese society, Confucianism has largely disappeared from children's education and many educational experts (although not all) believe that Confucian education is old-fashioned and unhelpful for enhancing children's thinking. It is true that cultural circumstances change and these changes demand a response; however, finding ways to re-use existing resources, such as the Analects of Confucius, may be a better way forward, since they are in keeping with the changing demand. Many of Confucius' concepts and knowledge contained in the Analects are as applicable today as they were when they were first written. Therefore, this research applies one of the conventional classical Chinese books, the Analects of Confucius, to develop children's critical thinking and moral reasoning in a primary school in Taiwan, contrasting use of this with the use of stories about moral dilemmas.

\section{Theory}

Confucius's educational ideas can be found in the Analects. Lee (2000) quotes a Confucian educational thought, "In old days men studied for the sake of one's own self; nowadays it is for the sake of [showing off to] others", and this prominent sentence, known to generations of 
pupils, best sums up the educational ideals of conventional Chinese culture. Found in the Analects $(L u n-Y u)$, the statement expressively describes the purpose of education, which is that education is meaningful as the individual development of one's own self. Although the Analects is mainly concerned with moral advancement, the obvious hint is that learning can also be pleasant. Either way, Confucian teaching is centred on personal enhancement, rather than on its helpfulness for acquiring recognition or benefitting one's self. Muller (2000) points out that there are chapters in the Analects in which the most significant point of reference may change in certain situations. For example, when Confucius says "filial piety (xiao 孝) is the great root of heaven and earth" , he is describing filial piety as being something comparatively fundamental. This could similarly be said, in terms of the situation, of the ideas of “righteousness” (yi 義), “wisdom” (zhi 智) and “propriety” (li 禮). There is no fixed and absolute “essence” of original Chinese philosophy, and so, no such concept exists in the Analects. However, there is one notion which shows its comparative "essentiality", acting as the most primary foundation for all figures of virtuous behaviour and qualities, and this is the concept of "benevolence" (仁 ren).

In the Analects, many particular and replicated key words in Confucius's sayings represent profound meanings from antiquity. Chen (2006) and Waley (1989) describe some characteristically essential words as follows: Ren 仁 is "Benevolence and Humanity"; De 
德 relates closely to the Latin virtus. It signifies, just as virtus does, the explicit quality or 'virtue' underlying anything; $Y i$ 義 is the traditional Chinese character for “justice” ; $L i$ 禮 translates closely as “Propriety or Rites” ; Zhi 知, as knowing, means “realising and obtaining knowledge” ; Xin 信 means “Trust”; Zhong 忠 is “Loyalty”; Zheng 正 refers to “Correctness, Propriety, Legality or Rectifying” ; Xue 學 is “Learning”; Xing 行 implies "Action and Practice or Conduct" . The Analects underline the moral principles by which to educate people. Confucius educated people, not only to acquire knowledge, but also to think in-depth and independently based on morals, to cultivate personal morality. At root then, this is an approach to developing people's thinking, framed in terms of the development of personal morality. However, there had no work to carry out the Analects to develop students' critical thinking. Some researches (Waley, 1989; Muller, 2000; Chen 2006) mainly regarded it as developing people's morality. Thus, this study explored moral philoshophy in the Analects further to cultivate students' critical thinking.

Confucius employed a heuristic approach to education to develop his students' capacity to think autonomously. He encouraged his pupils to think, observe and study more, and scrutinise their demeanour in order to cultivate benevolence (Chen, 2006). Based on Eastern philosophical concepts, Kim (2003) claims that Confucius' principle of learning is not passive, but contains a critical thinking element in that Confucius supports reflection in 
learning. Thus, making the Analects an explicit tool for teaching moral reasoning within a dialogic pedagogical approaches is one way to develop critical thinking, and the rationale for doing this is explored both theoretically and empirically in the following text.

Critical thinking can be regarded as being as much an attitude of mind and a disposition to reply as it is an exploitation of successful information-processing approaches (McGuinness, 1993). Ennis (1991) categorises dispositions of this kind into three broad aspects; taking care that one's confidence is not misplaced and one's judgment is justified; ensuring that one represents one's own and other people's standpoints openly and evidently; and ensuring that views of every person are acknowledged. A developmental perspective of curriculum materials can be framed to include these dispositions. Both moral reasoning and critical thinking are complex modes of thought, and cannot be learnt as sets of abstract principles. Although such an abstract understanding may be achieved eventually, it must be built by engaging with a range of specific experiences and the perspective of the participants of those experiences (Lipman, 1988; Ennis, 1996; Paul, 1990).

Vygotsky (1962) portrays language as a psychological tool, something each of us employs to make sense of experience. It is primarily through the method of spoken and written language that future generations benefit from the experience of their forebears. Thus, communication 
through language is a vital means to construct children's knowledge and understanding, and it is also essential for planning teaching activities to develop children's critical thinking. Dialogue is a communication structure that is compatible with the pluralistic standards of a democratic society, and it has long been adopted by teachers who are concerned with helping their pupils to become independent thinkers and active citizens (Reznitskaya, et al., 2009; Dewey, 1966; Freire, 1970; Kuhn, 1992). Dialogic methods in classroom teaching have been paid limited attention by researchers, although some of them have been mainly influenced by socio-cultural learning theories. These scholars have recently begun to design and use analytical structures to investigate classroom conversation and its use of dialogics (Reznitskaya, et al., 2009; Alexander, 2003; Mercer, Wegerif, \& Dawes, 1999; Nystrand, Wu, Garmon, Zeiser, \& Long, 2003). These studies provide significant information concerning teacher-student, student-teacher, and student-student interactions in the classroom (Reznitskaya, et al., 2009).

According to Fisher (2005), in order to apply philosophy efficiently in curricula to assist children's thinking, Lipman intends to pool children's social forces and apply dialogue as a process to expand their thinking. Lipman believed that the best approach to teach children to think was through stories and in order to prove his theory, he wrote a short children's novel entitled Harry Stottlemeier's Discovery (see Fisher 2005: 129). What Lipman intends to 
illustrate in the shape of the story is how children may behave in a real "community of enquiry'. He not only uses words to denote daily situations and how to apply them, but also philosophical themes, such as the essence of judgment and the working of the mind. The dialogue between the characters and their findings may be uncommon, but it is not exceptionally so. Thoughts related to the nature of ideas, intelligence, reality, and the exploitation of words have been the subject of philosophical disputes for centuries. Lipman claims that, if we want children to become thoughtful adults, Lipman claims, we must encourage them to be thoughtful children. When children discuss questions, they begin to learn that merely having an opinion is insufficient; rather, they must have reasons to validate their judgment. Their words must obviously express denotation, and they must raise characteristics with instances to be set as counter-arguments, and expand ideas to their logical conclusion. Additionally, the Education Endowment Foundation (2015) conducted Philosophy for Children by means of dialogues to help children to achieve higher academic attainment in terms of maths, reading, and writing. The result showed effects of +0.2 . This is supposed to be likely to introduce children to philosophy in another way by means of supportive dialogue.

Addressing this possibility reveals complex tensions. Mercer and Littleton (2007) maintain that education is a dialogic process between pupils and teachers, operated within schools, and 
the values and social practices of schools are regarded as being cultural foundations. The development of children's moral reasoning and critical thinking, and the potential role of peer-interaction and classroom conversation, are considered using a variety of theoretical frameworks. The use of philosophical moral materials within classroom conversation to develop children's critical thinking (Fisher, 2005) is examined, with a focus on Stories for thinking (Fisher, 1996), which is a resource that aims to develop the thinking ability of primary-aged children. The contrasting claims of the Analects of Confucius to use philosophy to deliver moral education (Kim, 2003) are also considered.

Therefore, the central aim of this research is to examine the development of children's critical thinking in the context of moral reasoning, using materials derived from the classical Chinese Analects of Confucius and Western moral dilemma stories as part of peer interactive classroom conversation in primary schools in Taiwan. These two types of material require a somewhat different implementation. The sentences in the Analects are brief and make use of classical expressions, naturally lending themselves to interventions in which the participants read a sentence and discuss its potential meaning. The Western stories are usually employed in exercises in which the participants read a story and discuss some fundamental questions related to it. However, apart from these variations, the structure of the interventions is kept as similar as possible to facilitate a clear comparison. Therefore, the first question addressed by 
the research relates to the level of effectiveness of dialogic teaching in improving Taiwanese primary school children's critical thinking in the context of moral reasoning. The second question is whether dialogic lessons using the Analects differ in their effectiveness from those that employ 'moral dilemma' scenarios, while the third question concerns whether or not any of the effects related to 1) and 2) vary according to age group.

\section{Method}

\subsection{Participants}

Intact primary school classes (aged 7-8, 9-10, and 11-12 years) were assigned to the intervention conditions. The parents of approximately 270 pupils in these nine classes were asked for their agreement for their children to participate in the research, and 166 of them agreed. The pupils themselves also expressed their willingness to participate in the study. A total of 117 of these children were assigned to the research interventions, and the other 49 were allocated to the control condition. The classes were randomly assigned to the condition. The development of the children's critical thinking was examined in three intervention classes, one from each age group that participated in the dialogic teaching with the Analects, and again in a further three intervention classes, one from each age group that engaged in dialogic teaching with children's moral dilemmas stories, and in the three control classes. The experimental and control classes were checked for a match in terms of language grade level, 
as shown in Table 1.

\subsection{Language-test}

In order to determine if the children in the two intervention conditions and the control condition in each age group had equal ability in their first language (Mandarin), their school language learning results (presented in Table 1) were analysed using a one-way ANOVA. The language test, which examined vocabulary, grammar, reading comprehension and reasoning, assessed the pupils' achievement in their first language (Chinese) learning, relative to the norms for their age group. Since this test formed part of their mid-term examination, the data was not available until the fourth lesson of the intervention. The mean standardised language grades indicated that the participating children generally performed at a slightly lower level than the national average, especially the oldest age group. Although the differences between the classes within each age group were small, they became significant in the youngest and middle age groups $\left(F(2,60)=4.18, p<0.05, \eta^{2}=0.12\right.$; and $F(2,51)=4.92, p<0.05, \eta^{2}=$ 0.16 respectively). In the youngest age group, the two intervention classes had comparable language levels; however, the control class had a lower score. In the middle age group, the moral dilemma intervention class had a higher score than either the Analects intervention class or the control class. Although these were not huge variations, they still needed to be kept in mind in what followed. It should be noted that the variable nature of the pattern of 
differences, coupled with the fact that there were no differences between the classes in the oldest age group, suggests that it is unlikely that the observed variation was a function of the interventions themselves, even though the language tests were conducted after they had begun.

\subsection{Materials for the intervention}

The Analects of Confucius programme lasted for 12 weeks based on one 40-minute lesson per week. One or two comprehensible sayings were selected from the Analects for each lesson based on different grade levels. An iconography and a story related to each saying formed part of the material presented to pupils. The materials for lessons in the moral dilemma programme were chosen from Stories for Thinking. Both programmes were consistent with the relevant curriculum and the time that would normally be devoted to a single theme in a lesson. Examples of lesson plans using different materials for diverse age groups are presented in Appendix A.

The central concept of the Analects of Confucius emphasises "benevolence/humanity", and the content of this book is a record of the life and conversations of the remarkable Chinese educator, thinker, and philosopher, Confucius. The book consists of 20 chapters and 492 sections, and was compiled by Confucius's students after his death. The text in this book 
consists of brief statements, the educational meaning of which requires deep deliberation. For example, Zi yue: “Xing xian jin ye, xi xiang yuan ye." means that Confucius said, "By nature, all men are alike, but the differences in their environment and practices make them turn out differently.” (On Yang Huo 17.2)

Stories for Thinking (Fisher, 1996) contains 30 philosophical stories for children aged 7 to 11 to read and think about with the intention of cultivating their thinking, learning, and language abilities. It also contains target questions related to the theme of each story, which address issues such as the nature of honesty, reality, justice and friendship, with the aim of motivating and expanding children's thinking via reflection and discussion.

\subsection{The intervention: dialogic training in group work}

The intervention was implemented by the teacher-researcher in a series of twelve 40-minute lessons based on one lesson per week. These lessons took place in the individual study time before the official class time started. The participants did not stay in their original classroom, but moved to a different room for the intervention classes.

Each of the six experimental classes contained three to five small groups (4 to 6 children in a group). Three classes of different ages were assigned to the intervention that applied the 
Analects, while the other three classes with corresponding age groups were allocated to the intervention that used Stories for Thinking. The teacher-researcher conducted the interventions in all cases. The interventions ran over 12 weeks, and each 40-minute lesson was arranged to allow 10 minutes for pupils' individual reading, 20 minutes for a small group discussion, and 10 minutes for the conclusion. The teaching agenda was similar in both interventions. The pupils were given materials with different themes in every lesson, and each small group had a worksheet with either a sentence from the Analects or a question related to a moral dilemma story. The students were instructed to read the stories individually before discussing the meaning of the selected sentence or responding to the question in their small groups, keeping a record of their discussion on the worksheet. Each group had to conclude their discussion by arriving at a consensus to report back to the class. The teacher walked around each group to give them the appropriate support. For example, if the students had no ideas to propose their viewpoints, the teacher would provide some questions to lead their discussion. Recordings of selected groups' discussions were taken via an MP4 in each of the lessons to facilitate an analysis of the contents of the discussion.

The control class did not take any interventional instructions. However, in order to equate differential motivation, expectations and placebo effects to measure improvement, the study applied an active control class (Boot, Simons, Stothart, \& Stutts, 2013). Literature-based 
reading was the approach for the class. Literature reading has an important effect on the development of critical thinking. A reader must recognize patterns within text, fit details into these patterns, then relate them to other texts and remembered experiences (Critical Thinking and Literature-based Reading, 1997, p. 1). Accordingly, the teachers in the active control class gave them stories selected from the Analects and Stories for Thinking as same as the experimental classes. Thus, these students also read stories in a series of twelve 40 -minute lessons based on one lesson per week, one story for each lesson. The reading took place in individual study time as in the intervention classes. After reading, the teacher asked them to write a reflective essay in response to the story.

\subsection{Evaluation of Intervention}

The principal data from this aspect of the research consisted of interactive classroom conversations among pupils and the teacher-researcher, and the post-test essays. To analyse the former, transcripts of the audio record of classroom conversations were generated, and then analysed using content analysis based on dialogic coding. The post-test essays were analysed using dialogic coding with same categories as the classroom conversation. In terms of the dialogic coding, the categories employed were based on those identified by past researchers as constituting the predominant moves made in group work exchanges and in dialogue between teachers and children (Mercer, 1996; Howe, Tolmie, Duchak Tanner \& 
Rattray, 2000). The crucial consideration in adopting these was that they also provided a map of the key aspects of critical thinking, such as the proposition, elucidation, and relative evaluation of a set of ideas. The codes used are detailed below.

1. 'Proposition' (Pr): pupils provide an idea or action or make a relevant statement.

2. 'Disagreement' (Dg): pupils oppose a proposition or explanation offered by another child.

3. 'Explanation' (Ex): pupils provide a rationale for a proposition.

4. 'Elaboration' (El) : pupils offer an interpretation at greater length or in great detail

5. 'Reference back' (Rb): pupils refer to a previous conversation in the dialogue.

6. 'Resolution' (R): pupils regulate, or agree with, another's statement in such a way as to resolve a dispute or disagreement.

7. 'Question' (Q): pupils provide an open-ended question (or some kind of prompt), which guides their thoughts to something not yet considered.

8. 'Teacher involvement' (T): teacher provides support, which guides pupils' thinking to something not yet discussed.

The categories of exploratory talk (Mercer, 1995; 1996) corresponded to the dialogic coding. The classification of their relationship is disputational talk, including a 'disagreement', cumulative talk containing a 'proposition', exploratory talk involving an 'explanation', 
'elaboration', 'reference back', 'resolution' and 'question'. The codes were applied to analyse each statement from the classroom conversation between the teacher-researcher and the pupils in the intervention groups across the three year-classes in the dialogic intervention. The reliability of this coding system was assessed using two inter-raters trained in the use of the categories. The proper size of the sample depends on factors, but it is would not be less than 50 units or $10 \%$ of the full sample (Neuendorf, 2002). Accordingly, the inter-raters independently coded $10 \%$ of the responses to the open-ended questions. The same two coders also coded $10 \%$ of the audio recordings of the dialogue in each intervention class, and $10 \%$ of the children's post-test essays. The results of the interrater analysis were Kappa $=0.718$ with $p<0.001$. In terms of the values of Kappa, from 0.40 to 0.59 is considered to be moderate, 0.60 to 0.79 substantial, and 0.80 outstanding (Landis \& Koch, 1977).

\subsection{Content analysis for dialogic coding}

Content analysis is a research method aimed at the impartial, systematic and quantitative depiction of the evident content of communication (Berelson, 1952; Krippendorff, 1980). An essential idea is that the numerous words of the text are sorted into much fewer content categories, each of which may be made of one, several, or many words. When making valid inferences from text, it is crucial that the categorisation process is reliable in the sense of being coherent: different people are supposed to code the same text in the same way (Weber, 
1990). However, the best content-analytic research has been argued to apply both qualitative and quantitative approaches to the source material (Bryman, 2008). This was the approach adopted here because the data consisted of diverse classroom talk between pupils and the teacher-researcher, and children's written essays, and it was considered than an authentic picture could not be gained by using only one approach.

As far as dialogic coding was concerned, the categories employed were based on those identified by past research as constituting the predominant moves made in group work exchanges and in dialogue between teachers and children (Mercer, 1996; Howe, Tolmie, Duchak-Tanner, \& Rattray, 2000). In adopting these, a crucial consideration was that these also provided a mapping of key aspects of critical thinking: the proposition, elucidation, and relative evaluation of a set of ideas.

\subsection{Post-test}

A language test and a written essay post-test were administered to participants in both the intervention and control classes. In the post-tests, all the pupils were required to write a reflective essay in response to a story that was similar to those provided as material for the small group discussions, although they had not previously discussed this specific moral dilemma or saying from the Analects. Half the children in each condition were assigned to 
write an essay on the topic of the moral dilemma, and the remaining half an essay on the selected Analects. The reliability of the coding system was evaluated using two interraters, and the result of the interrater analysis was Kappa $=0.762$ with $p<0.001$.

\subsection{Rating of the post-test}

The content of the post-test essays was evaluated using the same dialogic coding as the classroom conversation. As noted in the previous section, the 7 categories provide a map of the key features of critical thinking (except teacher involvement), and can therefore be used to assess the development of the children's argumentative skills. The use of the same scheme also made it possible to link the essay content to the evidence of critical thinking in the intervention groups, and the use of the same code helped to achieve an equivalently evaluated version to assess the improvement in thinking based on dialogue and the results of thinking from the written essay.

\section{Results}

\subsection{Dialogic intervention}

The coding scheme outlined above was applied to the conversations recorded in each of the 12 intervention lessons using the Analects and the moral dilemmas. The teacher's input was simply coded in terms of frequency of occurrence, rather than being broken down into 
separate codes. Having coded the pupils' dialogue, the total number of codes of each type was counted for each lesson, with separate totals being kept for each of the three recorded groups. These totals provided the raw data for the analysis. The descriptive statistics of class age and lesson type to the variance in the observed frequencies of the dialogue categories are illustrated in Tables 2 and 3 below.

In order to answer the research questions, the codes were combined into the three aspects of critical thinking (disputational (D), cumulative (C), and exploratory (E) talk) and used as dependent variables. A multivariate analysis of variance (MANOVA) was used to compare intervention groups and age with respect to the multivariate outcome of three talk groups and language-test scores on the dialogic intervention, as shown in Tables 4 and 5.

When the results of the dependent variables were considered separately, all apart from the pre-test reached a statistically significant difference with a large effect size. A one-way analyses of variance (ANOVA) and post hoc tests using a Bonferroni adjusted level of .01 were conducted on the dependent variables that were significant in the MANOVA (see Table 3). The results of the pre-test showed that age group 1 had significantly different higher scores than age group 3, indicating that the youngest students were assumed to have better improved their dialogic skills than the oldest ones. However, the results followed the same 
pattern as those for the treatment of dialogic talks, indicating that the older students had developed their exploratory talk significantly better than the youngest group.

The results of the pre-test on lesson type showed no significance, indicating that the participants in all intervention classes had equivalent language proficiency (see Table5). In the time 12 , exploratory talk was significantly different, indicating that the critical thinking of the participants who attended the Analects class had significantly improved compared to the participants in the moral dilemma class.

\subsection{Post-test}

Pupils' individual essays were scored using the same coding scheme as the dialogue, and the total frequencies of each of the eight relevant codes (i.e., excluding teacher involvement) were computed. Since the essays varied in length and thus in the opportunity for each code to arise, each pupil's totals were then divided by the number of words in his or her essay and multiplied by 100 , to give a uniform measure of the rate of occurrence of a given code per hundred words. The data for the eight codes was then analysed as three aspects of critical thinking as dependent variables for classes and age groups.

In order to answer the research questions, a one-way between-groups MANOVA was conducted to examine the intervention groups and age differences on dialogic treatment. The 
descriptive statistics (means and standard deviations) of critical thinking on the four dependent variables (pre-test, disputational talk, cumulative talk, and exploratory talk) are illustrated in Table 6. A MANOVA was conducted on two independent measures with three classes (A, B, and C), and three ages (1, 2, and 3).

There was a statistically significant difference between classes on the combined dependent variables, $F=4.179, p<.0001$; Wilks's Lambda $=.814$, partial eta squared $=.216$. When the results for the dependent variables were considered separately, all apart from the pre-test reached a statistically significant difference with a large effect size. A one-way analysis of variance and post hoc tests using a Bonferroni adjusted level of .01 were conducted on the dependent variables that were significant in the MANOVA (see Table 7). The results indicated that (a) the mean frequency of the exploratory talk for class A was higher than other classes; (b) there were no significant differences between class B and class C across the three tests.

There was a statistically significant difference between ages on the combined dependent variables, $F=20.032, p<.0001$; Wilks's Lambda $=.433$, partial eta squared $=.971$. A one-way analysis of variance and post hoc tests using a Bonferroni adjusted level of .01 were conducted on the dependent variables that were significant in the MANOVA (see Table 8). 
The results indicated that (a) the mean scores of the pre-test for age 1 and age 2 were higher than those for age 3, (b) the mean frequencies of cumulative talk for age 1were higher than those for age 2 and age 3, (c) there were no significant differences of disputational talk and exploratory talk among the three age groups.

\subsection{Relationship between the interventions and the post-test}

In order to determine the correlation between the treatments and the post-test, Pearson's product-moment correlation was used to analyse the three aspects of critical thinking. The results indicated that disputational talk and cumulative talk had a significantly moderate positive association $(\mathrm{r}=0.551, p<.05)$; cumulative talk and exploratory talk had a significantly moderate negative relationship $(\mathrm{r}=0.406, p<.01)$; cumulative talk and pre-test had a significantly weak positive correlation $(\mathrm{r}=0.247, p<.01)$, as shown in Table 9 below.

\section{Discussion}

In answer to the first and second research questions, the results indicate that, in terms of encountering critical thinking when applying the context of moral reasoning to dialogic teaching, the class type of the Analects contributed significant gains in the thinking of exploratory talk. A significant increase in the dialogic intervention was found, as shown in Table 4. Also, the results of the post-test illustrated a significant impact on the aspect of 
exploratory talk, as shown in Table 6. Thus, it can be argued that the children showed signs of their critical thinking having progressively shifted toward exploratory talk in the context of moral reasoning, and that the thinking ability of the children who received dialogic teaching in the class of the Analects generally improved compared with those in the moral dilemmas class and the controls.

According to Mercer's work on exploratory talk (1995, 1996, 2000, 2008), since communication skills are required for effective group work, the latter depends on preparing children to engage in authentic exploratory talk in classrooms; therefore, children should be supported to build the fundamental skills for such collaboration so that substantial talk can, in his terms, be utilised as a 'social mode of thinking'. If adhering to the argument that knowledge and meaning fundamentally intervene in the social processes of language, as claimed by Mercer (1996), whether or not participation among peers is consequential in promoting effective learning is founded on the quality of the discourse that takes place in collaborative group work activity (Reznitskaya, et. al., 2009). In the present research, in order to examine children's critical thinking in the context of moral reasoning by means of dialogic teaching, the focus was on seven key dialogue elements identified in previous research: proposing ideas, disagreeing, explaining, elaborating, referring back, resolving, and questioning (Howe \& Tolmie, 2003; Howe et al., 1995, 2000; Tolmie, Howe, Mackenzie, \& 
Greer, 1993). According to Mercer $(1995,1996)$, three forms of thinking and talking can be distinguished, namely, 'cumulative talk', 'disputational talk', and 'exploratory talk'. These provide an overarching framework for considering the pattern of occurrence of more specific dialogic categories and the extent to which this evidence progresses as a result of dialogic teaching.

This research applied materials with different cultural origins to two types of lessons to implement dialogic teaching. In terms of Collaborative Reasoning (CR) pedagogy (Reznitskaya, et. al., 2009), the Analects of Confucius contains Chinese classic philosophical analogies and aphorisms, and the pupils who encountered these materials discussed the meaning behind the selected brief extracts. Stories for Thinking (Fisher, 1996) consists of moral dilemma stories that have a more Western theme. The pupils who encountered material drawn from this discussed the moral question associated with each story, such as friendship, loyalty, truth, fairness, and so on. As already noted, the results revealed that the material of the Analects was more effective in developing the children's thinking toward exploratory talk. It was evident that more culturally-resonant materials could stimulate the students' thoughts and discussion.

The third question addressed by the research was whether or not any effects relating to 
questions one and two vary according to age group. The results showed that the older children produced exploratory talk with a significantly higher frequency than the youngest pupils in the dialogic intervention, as shown in Table 3. This implies that the older students progressed their thinking significantly toward exploratory talk in the context of moral reasoning by dialogic teaching. However, the results of the post-tests indicated that the youngest children had significantly higher language scores than the oldest ones (see Table 7). The youngest children also exhibited a significantly highest frequency on cumulative talk than other older age groups. A relationship of the three aspects of critical thinking between the interventions and the post-test was found, as shown in Table 8. Children with higher language scores engaged in cumulative talk better. As they developed their thinking toward exploratory talk, they produced less cumulative talk. Therefore, the oldest children were seen to have significantly improved their thinking toward exploratory talk in the context of moral reasoning by means of dialogic teaching. In turn, the youngest children merely developed their thinking toward cumulative talk.

This last result relates to the case that older children have to justify their intuition, which corresponds with idea of PI about the use of Socratic discussions and moral philosophy (Lipman, 1988). Children are expected to question, provide reasons, predict and theorise from a very young age, if only in the context of everyday activity. However, being 'open-minded' 
and having a balanced point of view needs knowledge of the self, as well as an understanding of others (Fisher, 2005). Thus, there remains a substantial gap, and providing teachers of the right age groups with direct experience of how to apply a group discussion in class using the most effective materials would seem to be the only way forward. It is hoped that the present research might go some way toward encouraging others to explore this possibility.

\section{Conclusion}

The aim of this study is to improve Taiwanese children's inferential ability to apply philosophy to enhance their moral reasoning and critical thinking by the employment of dialogic teaching in Taiwanese schools. A comparison of the lessons of the classical Chinese Analects of Confucius and Western moral dilemma stories made it possible to test this hypothesis. It also made it possible to assess whether or not dialogic interventions can generally be used to promote the growth of Taiwanese children's discursive skills over time and across the primary school age range. It can be concluded that there are relatively clear signs that the intervention class of the Analects led to improving pupils' ability to discuss the materials with which they were presented in a more critical and exploratory way. It is also notable that there were signs of benefit; however, these fit the picture that emerges from the dialogue data. The children in the two older age groups gained more from the Analects lessons, although the positive effects were limited to the Analects essay task rather than being 
spread more widely.

\subsection{Implications}

As an essentially exploratory piece of research, at least in the Taiwanese context, the main study achieved significant outcomes. Two relatively full programmes of dialogic teaching based on group work activities were developed and implemented with reasonably large cohorts and suitable control comparisons. The data obtained from the interventions and the post-test exercise provided a clear and consistent picture of the relative impact of the two forms of intervention at different ages. However, there were some limitations (e.g. no case-link other background variables to the analysis of group dialogue, its change over time, or to individual performance in the post-tests) in the design of the study, and a number of points that need to be addressed with follow-up research. The key priorities appear to be increasing the scale of research in this area and/or increasing the depth of detail of the data collected. 


\section{References}

Alexander, R. J. (2003). Talk for Learning: The First Year. Northallerton: North Yorkshire County Council.

Berelson, B. (1952). Content Analysis in Communications Research. New York: Free Press.

Boot, W. R., Simons, D. J., Stothart, C. \& Stutts, C. (2013). The pervasive problem with placebos in psychology: Why active control groups are not sufficient to rule out placebo effects. Perspectives on Psychological Science, 8(4), 445-454.

Bryman, A. (2008). Why do Researchers Integrate/Combine/Mesh/Blend/ Mix/Merge/Fuse Quantitative and qualitative Research? In Bergman, M. M. (2008) Advances in Mixed Methods Research. London: Sage.

Charles, M. (2015). The Analects of Confucius. Retrieved from http://www.acmuller.net/con-dao/analects.html.

Chen, W. H. (2006). Inspiration from Confucius. Singapore: FuIsland Offset Printing.

Critical Thinking and Literature-Based Reading. Report. Madison, WI: The Institute for Academic $\quad$ Excellence, $1997 . \quad$ Retrieved from http://www.eric.ed.gov/ERICWebPortal/custom/portlets/recordDetails/detailmini.js p?_nfpb=true\&_\&ERICExtSearch_SearchValue_0=ED421688\&ERICExtSearch_S earchType_0=no\&accno=ED421688.

Dewey, J. (1966). Democracy and Education. New York, NY: Macmillian.

Education Endowment Foundation. (2015). Philosophy for Children: Evaluation Report and Executive summary. Retrived from https://v1.educationendowmentfoundation.org.uk/uploads/pdf/Philosophy_for_Chil dren.pdf.

Ennis R. H. (1991). Critical thinking: A stream lined conception. Teaching Philosophy, 14 (1), 5-25.

Ennis, R.H. (1996). Critical Thinking. Upper Saddle River, NJ: Prentice Hall.

Fisher, R. (1996). Stories for Thinking. Oxford: Nash Pollock Publishing.

Fisher, R. (2005). Teaching Children to Think. Cheltenham: Nelson Thornes.

Freire, P. (1970). Pedagogy of the Oppressed. New York: Seabury.

Howe, C. J., \& Tolmie, A. (2003). Group work in primary school science: discussion, consensus and guidance from experts. International Journal of Educational Research, 39, 51-72.

Howe, C. J., Tolmie. A., Greer, K., \& Mackenzie, M. (1995). Peer collaboration and conceptual growth in physics: task influences on children's understanding of heating and cooling. Cognition and Instruction, 13, 483-503.

Howe, C. J., \& Tolmie, A., Duchak-Tanner, V. \& Ratrray, C. (2000). Hypothesis testing in science: Group consensus and the acquisition of conceptual and procedural knowledge. Learning and Instruction, 10, 361-391.

Kim, H. K. (2003). Critical Thinking, Learning and Confucius: A Positive Assessment. Journal of Philosophy of Education, 37 (1), 71-87.

Krippendorff, K. (1980). Content Analysis - An introduction to Its Methodology. CA: Sage. 
Kuhn, D. (1992). Thinking as argument. Harvard Educational Review, 62(2), 155-177.

Landis, J. R., \& Koch, G. G. (1977). The measurement of observer agreement for categorical data. International Biometric Society, 33(1), 159-174.

Lipman, M. (1988). Critical thinking: what can it be? Analytic Teaching, 8, 5-12.

McGuinness, C. (1993). Teaching Thinking: new signs for theories of cognition. Educational Psychology, 13 (3-4), 305-316.

Mercer, N., \& Littleton, K. (2007). Dialogue and the Development of Children's Thinking: A Sociocultural Approach. Abingdon: Routledge.

Mercer, N. (1995). The Guided Construction of Knowledge - Talk amongst teachers and learners. Clevedon: Multilingual Matters.

Mercer, N. (1996). The quality of talk in children's collaborative activity in the classroom. Learning and Instruction, 6, 359-377.

Mercer, N. (2000). Words and Minds: How We Use Language to Think Together. London: Routledge.

Mercer, N., Wegerif, R., \& Dawes, L. (1999). Children's talk and the development of reasoning in the classroom. British Educational Research Journal, 25 (1), 95-111.

Mercer, N., \& Dawes, L. (2008). The Value of Exploratory Talk. In N. Mercer, \& Hodgkinson (Eds), Exploring Talk in Schools: Inspired by the Work of Douglas Barnes (pp. 55-71). London: Sage Publications Ltd.

Muller, C. (2000). Tiyong and Interpenetration in the Analects of Confucius: The Sacred as Secular. Bulletin of Toyo Gakuen University, 8, 93-106.

Neuendorf, K. A. (2002). The Content Analysis Guidebook. Thousand Oaks, CA: Sage.

Nystrand, M., Wu, L., Garmon, A., Zeiser, S., \& Long, D. A. (2003). Questions in time: Investigating the structure and dynamics of unfolding classroom discourse. Discourse Processes, 35(2), 135-200.

Paul, R. W. (1990). Critical thinking: what every person needs to survive in a rapidly changing world. In A. J. A. Binker (Eds.), Centre for Critical Thinking and Moral Critique (pp. 45-56). U.S.A: Sonoma State University.

Reznitskaya, A., Kuo, L. J., Clark, A. M., Miller, B., Jadallah, M., Anderson, R. C., and Nguyen-Jahiel, K., (2009). Collaborative reasoning: a dialogic approach to group discussions. Cambridge Journal of Education, 39 (1), 29-48.

Tolmie, A., Howe, C. J., Mackenzie, M., \& Greer, K. (1993). Task design as an influence on dialogue and learning: Primary school group work with object flotation. Social Development, 2, 183-201.

Waley, A. (1989). The Analects of Confucius. New York: Vintage Books.

Weber, R. P. (1990). Basic Content Analysis. London: Sage. 


\section{Table and Figure}

Table 1. Participants' characteristics

\begin{tabular}{|c|c|c|c|}
\hline Age group & Condition class & Number of pupils & $\begin{array}{l}\text { Mean language grade } \\
\text { (Standard Deviation) }\end{array}$ \\
\hline \multirow{3}{*}{$\begin{array}{l}\text { Class A } \\
\text { (7-8 years, } \\
\text { Grade } 1)\end{array}$} & $\begin{array}{l}\text { Intervention A } \\
\text { (The Analects) }\end{array}$ & 25 & $97.76(2.17)$ \\
\hline & $\begin{array}{l}\text { Intervention A-1 } \\
\text { (Moral dilemma) }\end{array}$ & 18 & $97.11(2.46)$ \\
\hline & Control A & 23 & $95.57(2.31)$ \\
\hline \multirow{3}{*}{$\begin{array}{l}\text { Class B } \\
\text { (9-10 years, } \\
\text { Grade } 3)\end{array}$} & $\begin{array}{l}\text { Intervention B } \\
\text { (The Analects) }\end{array}$ & 17 & $93.65(4.89)$ \\
\hline & $\begin{array}{l}\text { Intervention B-1 } \\
\text { (Moral dilemma) }\end{array}$ & 26 & $97.15(2.79)$ \\
\hline & Control B & 14 & $94.71(2.95)$ \\
\hline \multirow{3}{*}{$\begin{array}{c}\text { Class C } \\
\text { (11-12 years, } \\
\text { Grade } 5)\end{array}$} & $\begin{array}{l}\text { Intervention C } \\
\text { (The Analects) }\end{array}$ & 17 & $88.59(9.36)$ \\
\hline & $\begin{array}{l}\text { Intervention C-1 } \\
\text { (Moral dilemma) }\end{array}$ & 14 & $89.36(8.39)$ \\
\hline & Control C & 12 & $91.67(4.10)$ \\
\hline
\end{tabular}

Table 2. Means for each element of dialogue broken down by time point (standard deviations in brackets)

\begin{tabular}{ccccccccc}
\hline & \multicolumn{1}{c}{ Dialogic skills } & \multicolumn{1}{c}{} \\
\cline { 2 - 7 } Time & $\mathrm{Pr}$ & $\mathrm{Dg}$ & $\mathrm{Ex}$ & $\mathrm{El}$ & $\mathrm{Rb}$ & $\mathrm{R}$ & $\mathrm{Q}$ & $\mathrm{T}$ \\
\hline \multirow{2}{*}{1} & 13.17 & 1.39 & 1.50 & 1.17 & 6.94 & 6.17 & 4.72 & 9.89 \\
& $(6.32)$ & $(1.24)$ & $(1.79)$ & $(0.71)$ & $(2.41)$ & $(3.07)$ & $(3.14)$ & $(3.71)$ \\
& 10.83 & 2.22 & 1.28 & 2.17 & 8.28 & 5.56 & 4.00 & 8.94 \\
4 & $(3.55)$ & $(1.52)$ & $(1.60)$ & $(0.79)$ & $(3.20)$ & $(2.71)$ & $(2.06)$ & $(2.89)$ \\
& 10.61 & 3.11 & 2.17 & 2.06 & 7.78 & 6.94 & 6.67 & 8.72 \\
\multirow{2}{*}{8} & $(4.87)$ & $(2.22)$ & $(1.58)$ & $(1.35)$ & $(4.74)$ & $(2.98)$ & $(3.74)$ & $(2.76)$ \\
& 11.33 & 3.39 & 1.61 & 3.28 & 7.89 & 7.61 & 7.94 & 5.22 \\
12 & $(4.09)$ & $(1.46)$ & $(1.15)$ & $(1.64)$ & $(3.34)$ & $(2.30)$ & $(4.37)$ & $(4.53)$ \\
\hline
\end{tabular}


Table 3. Mean for each element of dialogue broken down by age group and lesson type (standard deviations in brackets)

\begin{tabular}{|c|c|c|c|c|c|c|c|c|}
\hline \multirow[b]{2}{*}{ Age group } & \multicolumn{6}{|c|}{ Dialogic skills } & \multirow[b]{2}{*}{ Q } & \multirow[b]{2}{*}{$\mathrm{T}$} \\
\hline & $\operatorname{Pr}$ & $\mathrm{Dg}$ & Ex & $\mathrm{El}$ & $\mathrm{Rb}$ & $\mathrm{R}$ & & \\
\hline 1 ( $7-8$ years old $)$ & $\begin{array}{l}10.32 \\
(0.67)\end{array}$ & $\begin{array}{c}2.11 \\
(0.27)\end{array}$ & $\begin{array}{c}1.10 \\
(0.22)\end{array}$ & $\begin{array}{c}1.60 \\
(0.24)\end{array}$ & $\begin{array}{c}4.63 \\
(0.48)\end{array}$ & $\begin{array}{c}4.93 \\
(0.33)\end{array}$ & $\begin{array}{c}3.78 \\
(0.25)\end{array}$ & $\begin{array}{c}8.33 \\
(0.51)\end{array}$ \\
\hline $2(9-10$ years old $)$ & $\begin{array}{l}10.65 \\
(0.67)\end{array}$ & $\begin{array}{c}1.85 \\
(0.27)\end{array}$ & $\begin{array}{c}1.52 \\
(0.22)\end{array}$ & $\begin{array}{c}2.14 \\
(0.24)\end{array}$ & $\begin{array}{c}8.31 \\
(0.48)\end{array}$ & $\begin{array}{c}7.76 \\
(0.33)\end{array}$ & $\begin{array}{c}6.36 \\
(0.25)\end{array}$ & $\begin{array}{c}8.61 \\
(0.51)\end{array}$ \\
\hline 3 (11-12 years old) & $\begin{array}{l}13.96 \\
(0.67) \\
\end{array}$ & $\begin{array}{c}3.22 \\
(0.27) \\
\end{array}$ & $\begin{array}{c}1.75 \\
(0.22) \\
\end{array}$ & $\begin{array}{c}2.83 \\
(0.24) \\
\end{array}$ & $\begin{array}{c}9.44 \\
(0.48) \\
\end{array}$ & $\begin{array}{c}6.85 \\
(0.33) \\
\end{array}$ & $\begin{array}{c}7.74 \\
(0.25) \\
\end{array}$ & $\begin{array}{c}6.54 \\
(0.51) \\
\end{array}$ \\
\hline \multicolumn{9}{|l|}{ Lesson type } \\
\hline The Analects & $\begin{array}{l}12.82 \\
(0.54)\end{array}$ & $\begin{array}{c}2.62 \\
(0.22)\end{array}$ & $\begin{array}{c}1.06 \\
(0.18)\end{array}$ & $\begin{array}{c}2.35 \\
(0.19)\end{array}$ & $\begin{array}{c}8.44 \\
(0.39)\end{array}$ & $\begin{array}{c}7.00 \\
(0.27)\end{array}$ & $\begin{array}{c}6.51 \\
(0.20)\end{array}$ & $\begin{array}{c}7.89 \\
(0.41)\end{array}$ \\
\hline Moral dilemma & $\begin{array}{l}10.47 \\
(0.54)\end{array}$ & $\begin{array}{c}2.17 \\
(0.22)\end{array}$ & $\begin{array}{c}1.85 \\
(0.18)\end{array}$ & $\begin{array}{c}2.03 \\
(0.19)\end{array}$ & $\begin{array}{c}6.48 \\
(0.39)\end{array}$ & $\begin{array}{c}6.02 \\
(0.27)\end{array}$ & $\begin{array}{c}5.41 \\
(0.20)\end{array}$ & $\begin{array}{c}7.76 \\
(0.41)\end{array}$ \\
\hline
\end{tabular}

Table 4. Results of analysis of variance by age group across dialogic interventions

\begin{tabular}{|c|c|c|c|c|c|c|c|c|}
\hline \multirow{2}{*}{ Time } & & Intervention & $S S$ & $d f$ & $M S$ & $F$ & $p^{*}$ & Post hoc tests \\
\hline & Pre-test & & 78.00 & 2 & 39.00 & 17.64 & .022 & $1>3$ \\
\hline \multirow{3}{*}{1} & & $\mathrm{D}$ & 4.78 & 2 & 2.390 & 1.72 & .220 & \\
\hline & & $\mathrm{C}$ & 109.00 & 2 & 54.50 & 1.67 & .229 & \\
\hline & & E & 15.77 & 2 & 7.89 & 4.14 & .043 & $2>1$ \\
\hline \multirow{3}{*}{4} & & D & 5.44 & 2 & 2.72 & 1.07 & .375 & \\
\hline & & $\mathrm{C}$ & 24.11 & 2 & 12.07 & .882 & .439 & \\
\hline & & $\mathrm{E}$ & 12.07 & 2 & 6.04 & 13.06 & .001 & $2>1 ; 3>1$ \\
\hline \multirow{3}{*}{8} & & $\mathrm{D}$ & 19.44 & 2 & 9.72 & 2.16 & .158 & \\
\hline & & $\mathrm{C}$ & 60.78 & 2 & 30.39 & 1.41 & .282 & \\
\hline & & $\mathrm{E}$ & 33.44 & 2 & 16.72 & 13.44 & .001 & $2>1 ; 3>1$ \\
\hline \multirow{3}{*}{12} & & $\mathrm{D}$ & 11.44 & 2 & 5.72 & 3.43 & .066 & \\
\hline & & $\mathrm{C}$ & 97.33 & 2 & 48.67 & 3.84 & .051 & \\
\hline & & E & 20.64 & 2 & 10.32 & 17.59 & .000 & $2>1 ; 3>1$ \\
\hline
\end{tabular}

*Alpha level set at $p<.01$.

Table 5. Results of analysis of variance by lesson type across dialogic interventions

\begin{tabular}{|c|c|c|c|c|c|c|c|}
\hline \multirow{2}{*}{ Time } & \multicolumn{2}{|r|}{ Intervention } & $S S$ & $d f$ & $M S$ & $F$ & $p^{*}$ \\
\hline & Pre-test & & 6.55 & 1 & 6.55 & 0.12 & .731 \\
\hline \multirow{3}{*}{1} & & D & 4.50 & 1 & 4.50 & 3.24 & .097 \\
\hline & & $\mathrm{C}$ & 93.39 & 1 & 93.39 & 2.86 & .117 \\
\hline & & E & 0.11 & 1 & 0.11 & 0.06 & .815 \\
\hline \multirow{3}{*}{4} & & D & 0.89 & 1 & 0.89 & 0.35 & .566 \\
\hline & & $\mathrm{C}$ & 80.22 & 1 & 80.22 & 5.87 & .032 \\
\hline & & $\mathrm{E}$ & 0.27 & 1 & 0.27 & 0.58 & .460 \\
\hline \multirow{3}{*}{8} & & D & 8.00 & 1 & 8.00 & 1.78 & .207 \\
\hline & & $\mathrm{C}$ & 68.06 & 1 & 68.06 & 3.16 & .101 \\
\hline & & $\mathrm{E}$ & 14.58 & 1 & 14.58 & 11.72 & .005 \\
\hline \multirow{3}{*}{12} & & D & 0.56 & 1 & 0.56 & 0.03 & .858 \\
\hline & & $\mathrm{C}$ & 0.89 & 1 & 0.89 & 0.70 & .796 \\
\hline & & $\mathrm{E}$ & 18.00 & 1 & 18.00 & 30.69 & .000 \\
\hline
\end{tabular}

*Alpha level set at $p<.01$. 
Table 6. Descriptive statistics of the groups in the MANOVA test

\begin{tabular}{|c|c|c|c|c|c|c|}
\hline \multirow{2}{*}{$\begin{array}{c}\text { Learner } \\
\text { factors }\end{array}$} & \multirow{2}{*}{ Categories } & \multirow{2}{*}{$\mathbf{N}$} & \multirow{2}{*}{ Pre-test } & \multicolumn{3}{|c|}{ Post-tests } \\
\hline & & & & disputational talk & cumulative talk & exploratory talk \\
\hline \multirow{5}{*}{ Class } & $\begin{array}{c}\mathrm{A} \\
\text { (the Analects) }\end{array}$ & 59 & $\begin{array}{l}94.22 \\
(6.64)\end{array}$ & $\begin{array}{c}0.12 \\
(0.42)\end{array}$ & $\begin{array}{c}3.69 \\
(3.10)\end{array}$ & $\begin{array}{c}4.25 \\
(2.57)\end{array}$ \\
\hline & B & & 95.26 & 0.05 & 3.39 & 2.76 \\
\hline & (Moral dilemma) & 58 & (5.69) & $(0.24)$ & $(3.08)$ & $(2.42)$ \\
\hline & $\mathrm{C}$ & & 94.37 & 0.05 & 4.68 & 1.81 \\
\hline & (Control) & 49 & $(4.25)$ & $(0.26)$ & (3.03) & $(1.93)$ \\
\hline \multirow{4}{*}{ Age } & $\begin{array}{c}1 \\
(\text { Age } 7-8)\end{array}$ & 66 & 96.82 & 0.10 & 6.32 & 2.87 \\
\hline & $\begin{array}{c}\text { (Age 7-8) } \\
2\end{array}$ & & $\begin{array}{l}(3.28) \\
05.51\end{array}$ & $\begin{array}{c}(0.41) \\
0.05\end{array}$ & $\begin{array}{c}(3.14) \\
2.34\end{array}$ & $\begin{array}{c}(2.82) \\
2.64\end{array}$ \\
\hline & (Age 9-10) & 57 & $\begin{array}{l}95.51 \\
(3.84)\end{array}$ & $\begin{array}{c}0.05 \\
(0.23)\end{array}$ & $\begin{array}{l}2.34 \\
(1.59)\end{array}$ & $\begin{array}{l}2.64 \\
(1.76)\end{array}$ \\
\hline & $\begin{array}{c}3 \\
(\operatorname{Ago} 112)\end{array}$ & 43 & 90.09 & 0.07 & $\begin{array}{l}2.17 \\
(189)\end{array}$ & $\begin{array}{l}3.70 \\
(285)\end{array}$ \\
\hline
\end{tabular}

Table 7. Results of analyses of variance across tests by class

\begin{tabular}{lrrrrrr}
\hline & \multicolumn{1}{c}{$S S$} & $d f$ & \multicolumn{1}{c}{$M S$} & \multicolumn{1}{c}{$F$} & \multicolumn{1}{c}{$p^{*}$} & Post hoc tests \\
\hline Pre-test & 21.749 & 2 & 10.874 & .446 & .641 & \\
Disputational talk & .113 & 2 & .056 & .553 & .576 & \\
Cumulative talk & 17.354 & 2 & 8.677 & 1.528 & .220 & \\
Exploratory talk & 157.084 & 2 & 78.542 & 15.213 & .000 & $1>2 ; 1>3$ \\
\hline
\end{tabular}

*Alpha level set at $p<.01$.

Table 8 . Results of analyses of variance across tests by age

\begin{tabular}{lrrrrrr}
\hline & \multicolumn{1}{c}{$S S$} & $d f$ & \multicolumn{1}{c}{$M S$} & \multicolumn{1}{c}{$F$} & \multicolumn{1}{c}{$p^{*}$} & Post hoc tests \\
\hline Pre-test & 1147.667 & 2 & 573.834 & 23.547 & .000 & $1>3 ; 2>3$ \\
\hline Disputational talk & .049 & 2 & .024 & .240 & .787 & \\
\hline Cumulative talk & 617.912 & 2 & 308.956 & 54.392 & .000 & $1>2 ; 1>3$ \\
\hline Exploratory talk & 13.853 & 2 & 6.926 & 1.342 & .264 & \\
\hline
\end{tabular}

*Alpha level set at $p<.01$.

Table 9. Correlation among three aspects of critical thinking

\begin{tabular}{ccccc}
\hline & Disputational talk & Cumulative talk & Exploratory talk & pre-test \\
\hline Disputational talk & --- & $.551^{*}$ & -.004 & .025 \\
Cumulative talk & & --- & $-.406^{* *}$ & $.247^{* *}$ \\
Exploratory talk & & & --- & -.079 \\
$\quad$ pre-test & & & & --- \\
\hline
\end{tabular}

$* p<0.05 \quad * * p<0.01$ 


\section{Appendix A}

\section{Example of lesson plans}

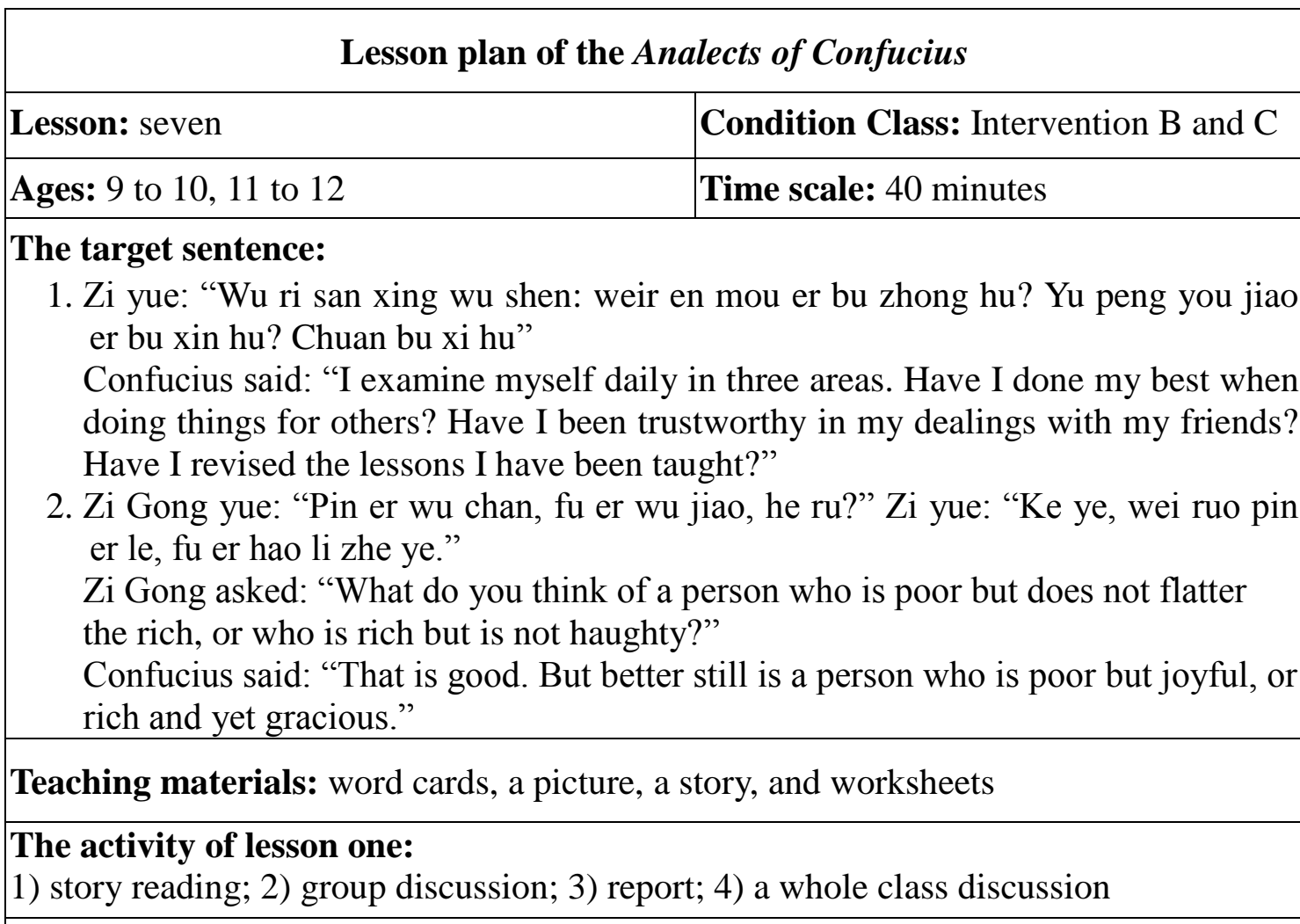

\section{The aim of this lesson:}

This is the seventh lesson. This lessons aims to reinforce pupils to implement collaborative work more autonomously, and develop in-depth reasoning as a means of communication skills and argumentative skills.

\section{The role of teacher in this lesson}

1) to circulate among every group; 2) to monitor group-works; 3) to help pupils when they encounter difficulties; 4) to train individual pupils and groups in collaborative skills.

\section{The strategy in this lesson}

1) to improve pupils' social skills in group discussions

2) to teach pupils to apply communications skills and argumentative skills

3) to remind every group to re-allocate the role

4) to encourage all pupils to think deeply and talk broadly

5) to support all groups' implementation of collaborative work

6) to stimulate more debates to echo other groups' viewpoints in the whole class discussion. 


\section{Process of this lesson:}

Warm up

1. The teacher guides pupils to review the target sentence in former lessons.

3 minutes

- The teacher offers a sentence and requires an explanation from Focus: pupils or provides a description to identify the correct sentence.

1. Story reading: pupils read a story individually.

- Every pupil will be given a story. One of three different stories related to three different target sentences is assigned to different groups by the teacher.

- Pupils should read a story individually within 10 minutes.

2. Briefing and debriefing the skills of a group discussion.

- Every group should reflect on what they should improve and evaluate how they need to change in this lesson.

- The teacher will remind groups to think about what they are looking for in a small group discussion.

3. Group discussion: Every group should discuss the denotation of their target sentence in terms of relevant stories.

- Students need to discover the appropriate explanation of their target sentence, and make a consensus in the group discussion.

- The teacher will circulate and monitor every group, as well as provide the appropriate supports. However, she will reduce her involvement in the discussion.

- Also, every group has to work on a single output, and write the explanation on the sheet as a group.

4. Reports and the whole class discussion: the spokesperson of each group should present the conclusion of their group discussion.

- The representative of every group reports the consensus from their group discussion.

- During the presentations, the teacher will encourage students to provide more feedback as a means of enhancing their argumentative skills to promote a more interactive discussion in the whole class conversation.

\section{Ending}

1. The teacher summarises all the discussion in this lesson, and gives the correct explanation of the target sentence. 
Lesson plan of Stories for Thinking

\begin{tabular}{|l|l|}
\hline Lesson: seven & Condition Class: Intervention B1 and C1 \\
\hline Ages: 9 to 10,11 to 12 & Time scale: 40 minutes \\
\hline
\end{tabular}

Topic: The Rocking Horse Winner (pp. 71-72)

Questions for discussion:

1. Are some people lucky? Can you give examples?

2. Are some people unlucky? Give some examples of bad luck.

3. Could an unlucky person have good luck? Can you give an example?

Teaching materials: a picture, a story, and worksheets

\section{The activity of lesson one:}

1) story reading; 2) group discussion; 3) report; 4) a whole class discussion

\section{The aim of this lesson:}

This is the seventh lesson. This lessons aims to reinforce pupils to implement collaborative work more autonomously, and develop in-depth reasoning in means of communication skills and argumentative skills.

\section{The role of teacher in this lesson}

1) to circulate around every group; 2) to monitor group-works; 3) to conduct pupils when they meet difficulties; 4) to train individual pupils and groups in-collaborative skills.

\section{The strategy in this lesson}

1) to improve pupils' social skills in group discussion

2) to progress pupils to apply communications skills and argumentative skills

3) to remind every group to re-allocate the role

4) to encourage all pupils think deeply and talk broadly

5) to support all groups to implement collaborative work

6) to stimulate more debates to echo other groups' viewpoints in the whole class discussion. 


\section{Process of this lesson:}

Warm up

2. The teacher guides pupils to review the target sentence in former lessons.

Focus:

- The teacher offers a sentence to require the explanation from pupils or provides description to inquire the correct sentence.

5. Story reading: pupils read a story individually.

- Every pupil will have a story. There are three different stories in 10 minutes terms of three different target sentences, which are assigned to different groups by the teacher.

- Pupils should read a story individually within 10 minutes.

6. Briefing and debriefing the skills of group discussion.

- Every group should reflect what they should improve and 3 minutes evaluate how they need to change in this lesson.

- The teacher will remind groups to think what they are looking for in small group discussion.

7. Group discussion: Every group should discuss the denotation of their target sentence in terms of relevant stories.

- Students need to discover the appropriate explanation of their target sentence, and make the consensus in group discussion.

- The teacher will circulate and monitor every group, as well as provides proper supports. However, she will decrease her involvement in the discussion.

- Also, every group has to work on a single output, and write the explanation up on the sheet as a group.

8. Reports and the whole class discussion: the spokesperson of each group should present the conclusion of their group discussion.

- The representative of every group reports the consensus from their group discussion.

- Among presentations, the teacher will stimulate students to provide more feedbacks in means of argumentative skills to occur more interactive discussion in the whole class conversation.

\section{Ending}

2. The teacher summarises all discussion in this lesson, and give the correct explanation of the target sentence. 